\title{
Stem cells: ray of hope in infertility
}

\section{Keywords: stem cells, SCT, oocytes, spermatogenesis}

\section{Introduction}

Stem cells (SCs) are the new weapon in this era against many diseases and disorders. To start with SCs only from bone marrow were in use. In that era stem cell therapy (SCT) was under development. Later it advanced and now a day's variety of SCs is available for research and therapy. This includes mesenchymal, neural epidermal, embryonic, limbal, induced pleuripotent and many others. ${ }^{1}$ Most 6000 studies are registered with National Institute of Health, US with maximum are for leukemia and infections. ${ }^{2}$

Many researchers worldwide are working on the problem of infertility. Stem cells seem to be an important mode of therapy for this problem. Infertility is the term labeled if a couple fails to achieve pregnancy even after 1 year of unprotected intercourse. ${ }^{3}$ Being infertile has major on the overall psychological as well as social profile of an individual. Broadly divided as 'male factor' and 'female factor' infertility has SCT as an emerging modality of treatment.

Usually spermatogenesis has gone awry in male factor infertility. Spermatogenesis takes place in seminiferous tubules. Therefore spermatgonial stem cells which are key to the sperm production, have an important role. While the etiology of a severe male factor remains largely unknown, a few genetic defects Some structural and numerical chromosomal abnormalities along with Y-chromosome deletions, are associated with a severe male factor infertility. In addition to this sometimes it has been noted that certain gonadotoxic drugs, radiations and chemotherapy as a mode of treatment for some other diseases interferes with spermatogenesis. All these lead to male factor infertility.

This could be prevented by autologous transplantation of spermatogonial stem cells (SSCs). Transplantation of SSCs that are stored prior to cancer treatment is proposed as a means to restore fertility in childhood cancer survivors. This application involves transplantation of SSCs into the seminiferous tubules via the efferent duct or rete testis. Post-transplantation colonization, self-renewal and differentiation of SSCs occur in seminiferous tubules and normal spermatogenesis ensues. ${ }^{4-6}$

Stem cell-based strategies have also been tried for ovarian regeneration and oocyte production. It has been proposed as future clinical therapies for treating infertility in women. Some workers have demonstrated mitotically active germ cells in human ovaries that can be purified and cultured in vitro to spontaneously form oocytes. This proves unique potential to generate oocytes in vitro from isolated cells in reproductive-aged women who may have a depleted follicle pool from such genetic defects. ${ }^{7,8}$

All these efforts collectively add up to the possibility of the fruitful treatment of infertility. For men it will help to preserve the
Volume 3 Issue I - 2017

\author{
Arati AdheRojekar,' Mohit V Rojekar ${ }^{2}$ \\ 'Hinduja National Hospital \& Research Center, India \\ ${ }^{2}$ Rajiv Gandhi Medical College, India
}

Correspondence: Mohit $\bigvee$ Rojekar, Rajiv Gandhi Medical College, EI/0.3, Ground floor, Ashirwad CHS, Sector 15, Airoli, Navi Mumbai, India, Email drmohi44@gmail.com

Received: April 07, 2017| Published: June 29, 2017

reproductive ability even after losing capacity of spermatogenesis. In females this will support to lengthen the fertile window. Similar to males, loss of fertility due to certain reasons like radiotherapy or chemotherapy ovarian ability may be restored by stem cell transplant in females.

\section{Acknowledgements}

None.

\section{Conflict of interest}

The author declares no conflict of interest.

\section{References}

1. Pham PV. Clinical application of stem cells: An update 2015. Biomedical Research and Therapy. 2016;3(2):483-489.

2. Www.clinicaltrials.gov/ct2/results?term $=$ stem + cells

3. Zegers-Hochschild F, Adamson GD, de Mouzon J, et al. International Committee for Monitoring Assisted Reproductive Technology, and World Health Organisation. Fertil Steril. 2009;92(5):1520-1524.

4. Mulder CL, Zheng Y, Jan SZ, et al. Spermatogonial stem cell auto transplantation and germline genomic editing: a future cure for spermatogenic failure and prevention of transmission of genomic diseases. Hum Reprod Update. 2016;22(5):561-573.

5. Brinster RL, Zimmermann JW. Spermatogenesis following male germcell transplantation. Proc Natl Acad Sci USA. 1994;91:11298-11302.

6. Dores C, Alpaugh W, Dobrinski I. From in vitro culture to in vivo models to study testis development and spermatogenesis. Cell Tissue Res. 2012;349:691-702.

7. White YA, Woods DC, Takai Y, et al. Oocyte formation by mitotically active germ cells purified from ovaries of reproductive-age women. Nat Med. 2012;18(3):413-421.

8. Volarevic V, Bojic S, Nurkovic J, et al. Stem cells as new agents for the treatment of infertility: current and future perspectives and challenges. Biomed Res Int. 2014;2014:507234. 